\title{
Study of Anthocyanin Pigments Produced During Pickled Red Cabbage "Sauerkraut" Production
}

\author{
Murakami Tomoko*1, Hayashi Kazuya*2 and Tsukui Akio*1 \\ * 1 Tokyo Kasei Gakuin Junior College \\ 22, Sanban-cho, Chiyoda-ku, Tokyo 102-8341 \\ * 2 Department of Development, Wada Sugar Refining Co., Ltd. \\ 3-15-28, Chuo, Edogawa-ku, Tokyo 132-0021
}

In an effort to determine the anthocyanin (AN) pigment yield during the maturation of pickled red cabbage, the determination of $\mathrm{pH}$, acid content, salt level, absorbance, degree of browning and color tone and analysis by LC/MS and HPLC were conducted. The results indicate that the pickled red cabbage maturation method may be used in preparing AN pigments. (1) During the maturation of pickled red cabbage, a $\mathrm{pH}$ decrease accompanied an increase in acid content, and an increase in absorption rate was observed on days $5 \sim 9$. No notable browning ensued and the cabbage's color tone became deep red, which progressively darkened with maturation. (2) The structures of red cabbage AN pigments were estimated to be as follows: $\mathrm{P} 1:$ cyanidin $\llbracket \mathrm{Cy}\rceil 3-O-(2-O-\beta$ - D glucopyranosyl [Glc $])-\beta$-D-Glc $]-5-O$ - $(\beta$-D -Glc $)] ; \mathrm{P} 6:[\mathrm{Cy}-3-O-(2-O-(6-O-p$-coumaryl $[p \mathrm{C}]-\beta$ - D -

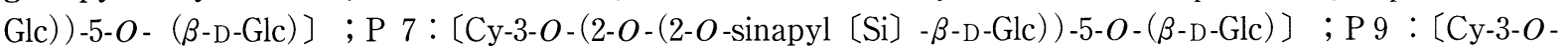
$(6-O-p \mathrm{C}-2-O-(2-O-\mathrm{Si}-\beta-\mathrm{D}-\mathrm{Glc}))-(5-O-(\beta-\mathrm{D}-\mathrm{Glc}))$; $\mathrm{P} 10$ : [Cy-3- $O$ - (6- $O$-ferulyl $〔 \mathrm{Fr}]-2-O-(2-O-\mathrm{Si}-\beta-\mathrm{D}-\mathrm{Glc}))-5-$ $O$-( $\beta$-D-Glc $)]$; and P11 : [Cy-3-O-(6-O-Si-2- $O$ - $(2-O$-Si- $\beta-\mathrm{D}-\mathrm{Glc}))-5-O-(\beta$-D-Glc) $]$. (3) The yield of total AN pigments was highest on days $5 \sim 9$ of the maturation of pickled red cabbage. Among the red cabbage AN pigments, P 1, a nonacylated AN, had the highest yield, which remained unchanged from days 0 through 21. However, the yields of $\mathrm{P} 6$ and $\mathrm{P} 7$, which are acylated AN pigments, increased up to day 9. These three pigments comprised the principal AN pigments of pickled red cabbage.

(Received Feb. 4, 2005 ; Accepted Jun. 23, 2005)

In the current practical preparation of $\mathrm{AN}$ pigments, red cabbage, red radish, elderberry, grape skin, perilla (shiso), grape juice, purple sweet potato and purple corn are often used as AN sources. AN pigment preparations are used in food products, and the demand for such pigment preparations from red cabbage is the largest at $120 \mathrm{t} /$ year $^{11}$. As a natural pigment, red cabbage AN provides familiar coloration and is safe to consumers; it is also a

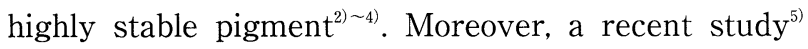
has suggested that AN pigments have some healthenhancement effects including the activation of the biological regulation function.

However, the extraction of AN pigments from red cabbage generally employs the dilute sulfuric acid method, which leaves some question on safety issues. Considering flavor and taste, the extraction of AN pigments with citric acid or lactic acid has been attempted; however this approach is costly.
We therefore studied an approach to preparing AN pigments by lactic acid fermentation using salted red cabbage. We utilized the residue following the AN pigment extraction in the production of a German lactic acid fermented food, sauerkraut (from red cabbage).

To establish the basic requirements to meet our objectives, examination was conducted with emphasis on the change in what of AN pigments during red cabbage pickling. AN pigment yield, $\mathrm{pH}$, acid content, salt level, absorbance, degree of browning and color tone were measured and highperformance liquid chromatography (HPLC) was performed. Analysis of the results obtained confirmed the effectiveness of the our method as an AN pigment extraction method.

* 1 E-mail : MuraKami Tomoko ; murakami@san.kasei-gakuin.ac.jp, TsukUI Akio ; tsukui@san.kasei-gakuin.ac.jp

* 2 E-mail : DY01210@nifty.ne.jp 


\section{Materials and Methods}

\section{Materials}

The variety of red cabbage (Brassica oleracea L.) used was Ruby Ball (TAKII \& Co., Ltd.) from Nagano. The salt used was purchased from Akoh Kaisui, K. K. (The Salt Industry Center of Japan).

\section{Pickling of red cabbage}

Following the sterilization of red cabbage [1.2kg] by immersing it in $70 \%$ ethanol, it was cut into appropriate sizes, and $3 \%$ (of the weight of the cut cabbage) salt and $1 \%$ cane sugar were added. An additional $300 \mathrm{~m} \ell$ of $7 \%$ salt solution was added to the solid mixture. Then, a $0.1 \%$ starter of lactic acid bacterial cells (Lactobacillus plantrum NRIC 1595) was added, and a lid was placed directly on the cabbage in a household pickling barrel. The Maturation temperature was $20 \sim 25^{\circ} \mathrm{C}$. The samples of red cabbage were allowed to mature for 5,9 , 15 and 21 days (pickled cabbage in salt solution before maturation was regarded as the material matured for 0 days).

\section{Extraction of AN pigments using various solvents}

After washing red cabbage with water, residual water was removed and the cabbage was cut into appropriate sizes. Then, an equal amount of $1 \%$ citric acid or $1 \%$ lactic acid solution was added to the cabbage. After soaking the cabbage for 5 days, AN was extracted. Presoaked ( 0 days of soaking) cabbage was also used in AN extraction for comparison.

\section{Preparation of analytical samples}

Analytical liquid samples were prepared by grinding pickled/matured cabbage samples soaked in various solvents with a mixer, adding an equal amount of pure water to the samples, centrifuging (3,000 rpm) for $10 \mathrm{~min}$, suction filtering the supernatant through a glass fiber filter paper (GA 100) and further filtering the samples through 0.45 $\mu \mathrm{m}$ Chromatodisk 13 A (Biofield Corporation).

\section{Constituent analysis}

(1) $\mathrm{pH}$ was determined using a $\mathrm{pH}$ meter (Horiba, Ltd. Model F-13). (2) Acid was quantified by titration using $0.1 \mathrm{M} \mathrm{NaOH}$ and the quantity of lactic acid was obtained. (3) Salt level was measured by the Mohl method using $0.05 \mathrm{M} \mathrm{AgNO}_{3}$. (4) Absorbance was determined using a spectrophotometer (Shimadzu Corporation Model UV -1200 ) at $525 \mathrm{~nm}$. (5) Degree of browning was calculated on the basis of spectrophotometric measurements at $420 \mathrm{~nm} / 525 \mathrm{~nm}$ using the Shimadzu Model UV-1200. (6) The color tone of the samples was determined using a color difference meter (Nippon Denshoku Industries Co., Ltd., Model ND$300 \mathrm{~B}$ ) and indicated in terms of $\mathrm{a}^{*}, \mathrm{~b}^{*}$ of the color system. (7) Pigment analysis was conducted by HPLC (Shimadzu Model SPD-M 10VA) using a diode array detector and a TSK gel ODS- 80 TM $(4.6 \mathrm{~mm}$ i.d. $\times 250 \mathrm{~mm}$ ) column (Tosoh Corporation). The column temperature was maintained at $45^{\circ} \mathrm{C}$, and the mobile phase comprised $0.1 \%$ trifluoroacetic acid and acetonitrile $(80: 20, \mathrm{v} / \mathrm{v})$ as eluant. The flow rate was maintained at $1.0 \mathrm{ml} / \mathrm{min}$ and AN pigment content (peak) was detected by monitoring absorbance at a wavelength of $525 \mathrm{~nm}$. (8) $\mathrm{AN}^{-}$ pigments were identified by HPLC-mass spectrometry (LC/MS). LC/MS analysis was conducted using HPLC equipment (Waters) to which a TSK gel ODS- $80_{\text {тм }}(4.6 \mathrm{~mm}$ i.d. $\times 250 \mathrm{~mm})$ column (Tosoh Corporation) was attached. The column temperature was maintained at $45^{\circ} \mathrm{C}$, and the mobile phase comprised $2 \%$ formic acid and acetonitrile $(80: 20, \mathrm{v} / \mathrm{v})$ as eluant. The flow rate was maintained at $0.8 \mathrm{~m} \ell / \mathrm{min}$. The mass spectrometer employed was TSQ 7000 (Finnigan MAT) with a data analyzer (Model DEC 3000) attached, and the ionization method employed was ESI (positive and negative ions). The ESI voltage was set at $4.5 \mathrm{kV}$.

\section{Results and Discussion}

\section{Changes in salt level, $\mathrm{pH}$ and acid content during maturation of pickled red cabbage}

Figure 1 shows the changes in salt level, $\mathrm{pH}$ and acid content during the maturation of pickled red cabbage. The salt level was about $2 \%$ and remained constant throughout the maturation period. The prematuration $\mathrm{pH}$ was 5.4 , which declined as maturation progressed; the $\mathrm{pH}$ of the sample on day 15 was 4.2 . The acidity prior to maturation was $0.25 \%$ and increased to $0.37 \%$ on day 15 . Subsequent changes in acid content up to day 21 were not observed.

\section{Changes in absorbance during maturation of pickled red cabbage}

Figure 2 shows the variation in absorbance at $\lambda$ $525 \mathrm{~nm}$ during the maturation of pickled red cabbage. The absorption rate increased up to day 9 and decreased subsequently. 

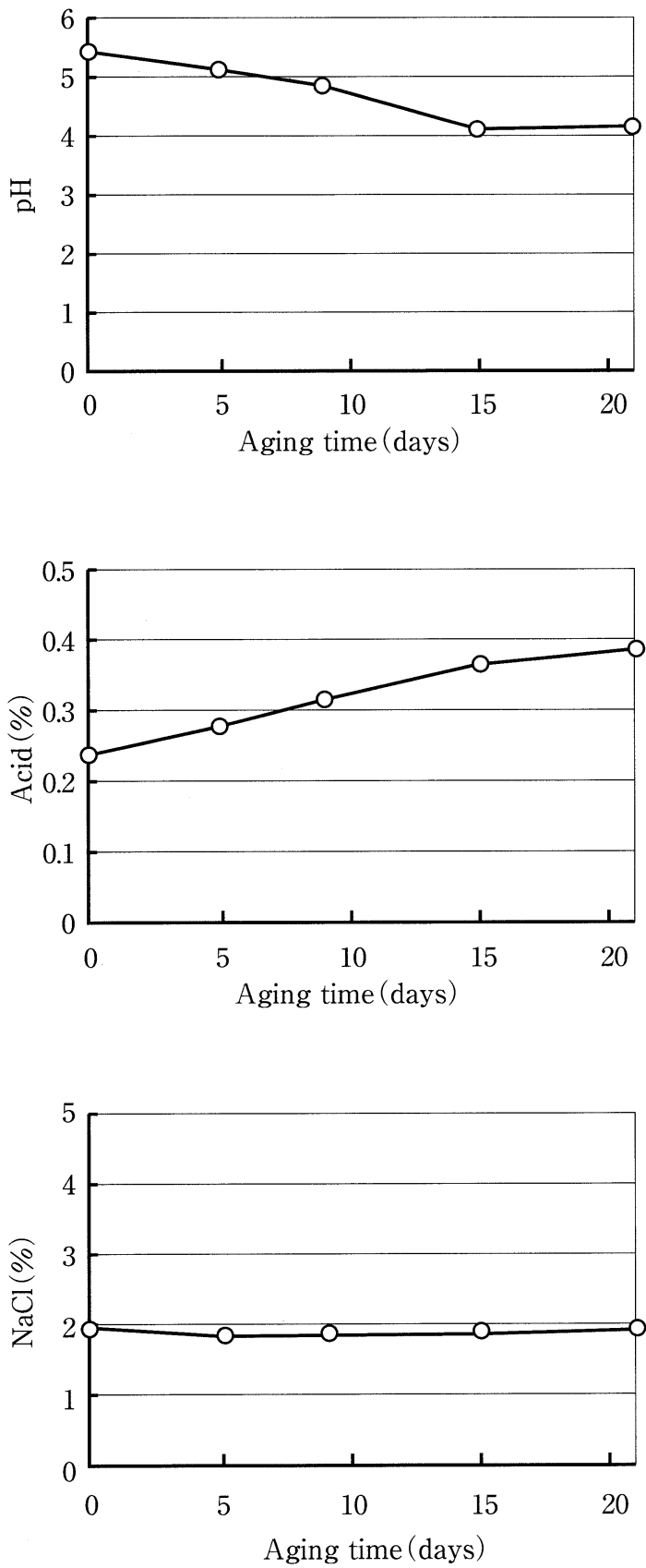

Fig. 1 Changes in salt level, pH and acid content during maturation of pickled red cabbage

\section{Change in degree of browning during maturation of pickled red cabbage}

The change in the degree of browning $(420 \mathrm{~nm} / 525$ $\mathrm{nm}$ ) is shown in Figure 3. As the absorbance (525 $\mathrm{nm}$ ) increased up to day 9 , the degree of browning decreased, while it increased between days 9 and 21 up to the prematuration level.

\section{Color tone change during maturation of pickled red cabbage}

Figure 4 depicts the color tone change during the maturation of pickled red cabbage in terms of

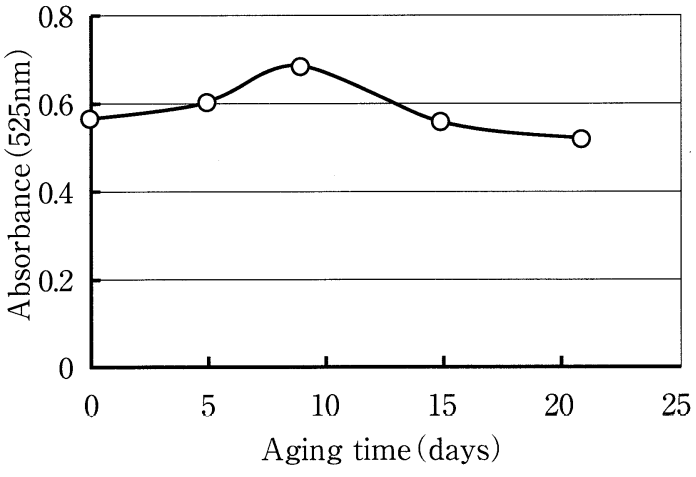

Fig. 2 Changes in absorbance during maturation of pickled red cabbage

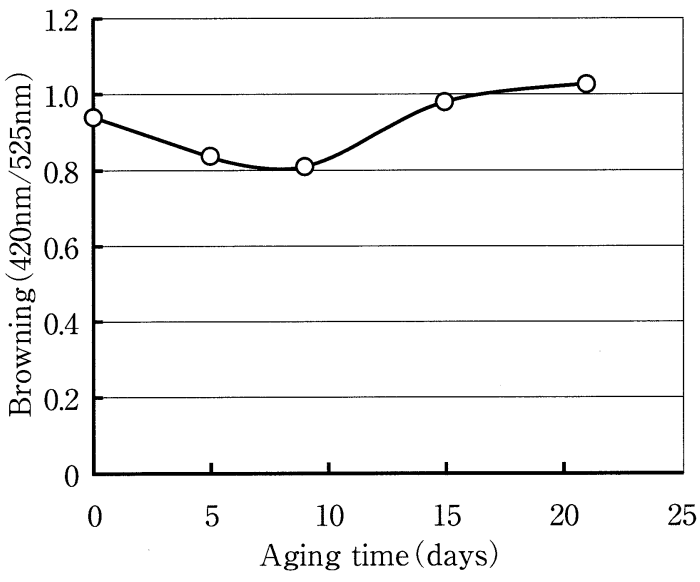

Fig. 3 Changes in degree of browning during maturation of pickled red cabbage

$\mathrm{L}^{*}, \mathrm{a}^{*}$ and $\mathrm{b}^{*}$ of the color system, in which the horizontal axis is $a^{*}$, the vertical axis $b^{*}$; chromaticness $\left(\mathrm{C}^{*}\right)$ is shown on the horizontal axis and luminosity $\left(\mathrm{L}^{*}\right)$ on the vertical axis. In the relationships of the $\mathrm{a}^{*}$ and $\mathrm{b}^{*}$ with the color tone, $\mathrm{a}^{*}$ moved in the positive direction on day 5 with the color tone showing dark red, while $\mathrm{a}^{*}$ moved in the negative direction from day 5 to day 9 with the color tone showing slightly diminished red, $b^{*}$ moved in the positive direction starting from day 10 until day 21. The tendency of the red color to darken was also confirmed from the relationship of $\mathrm{C}^{*}$ and $\mathrm{L}^{*}$ observed on day 21 of maturation.

\section{Effect of maturation of pickled red cabbage on total AN yield}

We measured AN level in pickled red cabbage during maturation by HPLC. The results are shown in Figure 5. The HPLC total peak areas on days 5 through 9 were the largest and the $\mathrm{AN}$ yields 

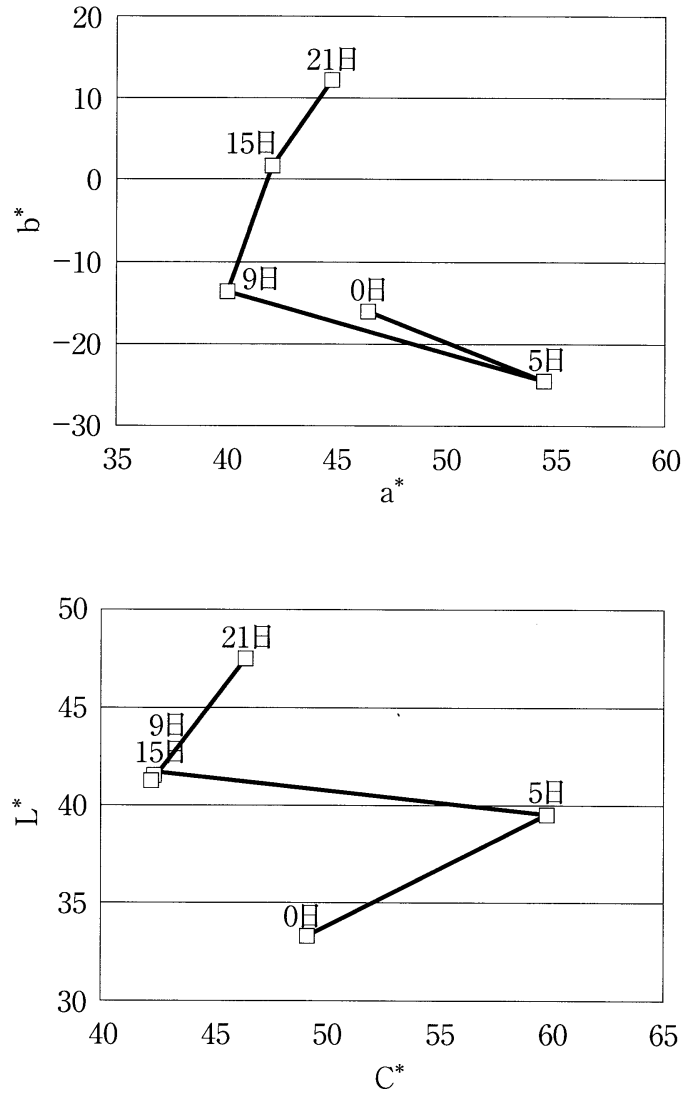

Fig. 4 Color tone change during maturation of pickled red cabbage

were favorable. As shown in Figure 1, pH decreased and acid content increased up to day 15 , while the HPLC total peak area decreased after day 9 probably because of the fading of AN induced by browning. Because the HPLC total peak area decreased as maturation progressed from days 15 through 21, a pickled red cabbage maturation period of approximately $5 \sim 9$ days was most suitable for AN extraction, from the standpoint of AN yield.

\section{6 . Identification of $\mathrm{AN}$ pigments in red cabbage}

We analyzed AN pigments in red cabbage by HPLC and the results are shown in Figure 6. The structures of AN pigments corresponding to 6 peaks, P1, P6, P 7, P 9, P10 and P11 were analyzed by LC/MS and estimated according to the molecule ion mass number of each pigment constituent, the analytical result of each fragment ion, and the relative retention time in HPLC as follows: P 1 : Cy 3-O-(2-O- $\beta$-D-Glc)- $\beta$-D-Glc)-(5- $O$ $(\beta-\mathrm{D}-\mathrm{Glc}) 【 \mathrm{M}^{+} 773 】 ; \mathrm{P} 6: \mathrm{Cy}-3-O-(2-O-(6-O-p \mathrm{C}-\beta-\mathrm{D}-$ $\mathrm{Glc}))-\left(5-O-(\beta-\mathrm{D}-\mathrm{GlC}) 【 \mathrm{M}^{+} 919\right\rfloor ; \mathrm{P} 7$ : Cy-3-O- $(2-O-(2-$ $O$-Si- $\beta$-D-GlC $))-\left(5-O-(\beta\right.$-D-Glc $) 【 \mathrm{M}^{+} 979 】 ; \mathrm{P} 9$ : Сy-3- $O$ - $(6-O-p \mathrm{C}-2-O-(2-O-\mathrm{Si}-\beta-\mathrm{D}-\mathrm{Glc}))-\left(5-O-(\beta-\mathrm{D}-\mathrm{Glc}) 【 \mathrm{M}^{+}\right.$ $1126 】$; $\mathrm{P} 10$ : Cy-3- $O-(6-O-\mathrm{Fr}-2-O-(2-O-\mathrm{Si}-\beta-\mathrm{D}-\mathrm{GlC}))-(5-$

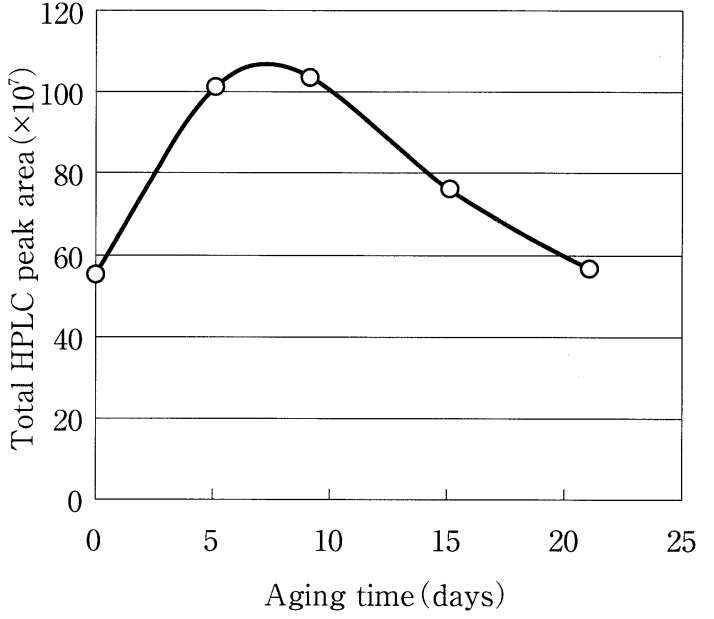

Fig. 5 Effect of maturation of pickled red cabbage on total AN yield

Pigments were analyzed with a TSK-gel ODS-80 9 тм $(4.6$ mmi.d $\times$ $250 \mathrm{~mm}, 5 \mu \mathrm{m}$ ) at $45^{\circ} \mathrm{C}$, using a solvent system (acetonitrile $-0.1 \%$ $\mathrm{TFA}=1: 4 \mathrm{v} / \mathrm{v})$ in the isocratic elution mode, at a flow rate of $1.0 \mathrm{~m} \ell / \mathrm{min}$ by monitoring at $525 \mathrm{~nm}$.

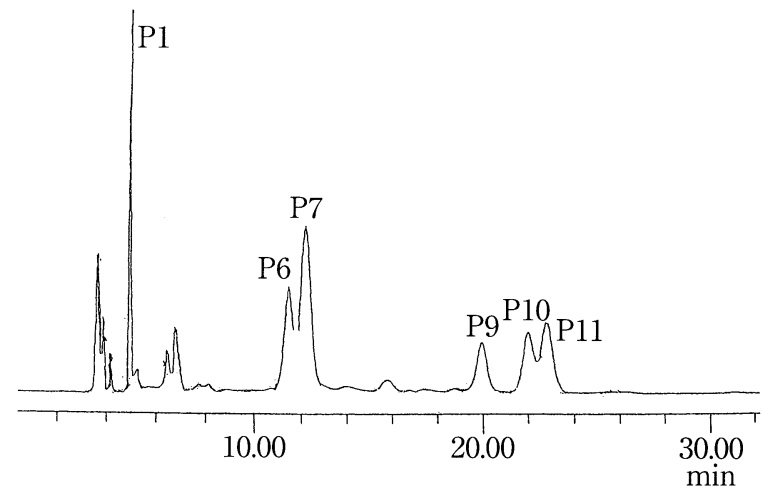

Fig. 6 HPLC chromatograms of red cabbage anthocyanin

HPLC conditions: same as those in Fig. 5.

P 1 : Cyanidin (Cy) 3- $O$-( $\beta$ - D- glucopyranosyl (Glc) )- $\beta$ - D- Glc) - 5$O-(\beta-\mathrm{D}-\mathrm{Glc})$

P 6 : Cy 3- $O$ - (6-p-coumaryl- $\beta$-D-Glc) $-\beta$-Glc) $-5-O$ - $(\beta$-D-Glc $)$ P 7 : Cy $3-O-(2-O-\sin a p y l(\mathrm{Si})-\beta-\mathrm{D}-\mathrm{Glc})-\beta-\mathrm{Glc})-5-O-(\beta-\mathrm{D}-\mathrm{GlC})$

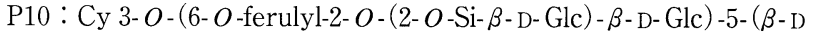
- Glc)

$\mathrm{P} 11: \mathrm{Cy} 3-O-(6-O-\mathrm{Si}-2-O-(2-O-\mathrm{Si}-\beta$ - D-Glc $)-\beta$ - D-Glc $)-5-O-(\beta-\mathrm{D}-$ Glc)

$O$ - $(\beta-\mathrm{D}-\mathrm{GlC}) 【 \mathrm{M}^{+} 1155 】$; and $\mathrm{P} 11: \mathrm{Cy}-3-O-(6-O-\mathrm{Si}-2$ $-O$ - $(2-O-\mathrm{Si}-\beta$-D-Glc $))$ - (5- $O$ - $\left(\beta\right.$-D-Glc) 【 ${ }^{+} 1185 】$. Red cabbage AN pigments comprised pigments having cyanidin as the aglycone and had a basic structure $(\mathrm{P} 1)$ in which sophorose (Glc $\beta 1 \rightarrow 2$ Glc) was bonded to the $3^{\text {rd }}$ position of the cyanidin and glucose was bonded to the $5^{\text {th }}$ position. In this basic structure, $p$-coumaric acid in $\mathrm{P} 6$, sinapic acid in $\mathrm{P}$ 7 , $p$-coumaric acid and sinapic acid in P 9 , ferulic acid and sinapic acid in P10, and 2 molecules of 
sinapic acid in P11 were ester-bonded to each form to form acylated $\mathrm{AN}$ pigments.

\section{Effect of solvents on extraction yield of principal AN}

AN pigments extracted from red cabbage using $1 \%$ citric or $1 \%$ lactic acid solutions showed peak areas of $\mathrm{P} 1, \mathrm{P} 6$ and $\mathrm{P} 7$ corresponding to principal AN pigments determined by HPLC. Results are shown in Figure 7.

In terms of the yield of the principal $\mathrm{AN}$ pigments obtained using $1 \%$ citric acid or $1 \%$ lactic acid, those obtained using the former ( $\mathrm{P} 1, \mathrm{P}$ 6 and P 7 ) were slightly higher. The yield of $\mathrm{P} 7$ was the highest, followed by those of P 6 and P 1 in that order.

\section{Changes in principal AN during maturation of pickled red cabbage}

The dynamics of the five principal types of $\mathrm{AN}$ from red cabbage during the maturation is shown in Figure 8. The AN yield was highest on days 5 $\sim 9$ of the maturation. However, there were differences in yield depending on the type of AN. In particular, the highest $\mathrm{AN}$ yield for $\mathrm{P} 7$ was obtained on day 5 and that for $\mathrm{P} 6$ on day 9 ; those for P 7, P 6 and P 1 comprised the principal AN pigments extracted from pickled red cabbage. The yields of AN pigments extracted using lactic acid and citric acid solutions were slightly higher than that of AN pigments extracted from the pickled red cabbage. Thus, the pickled red cabbage

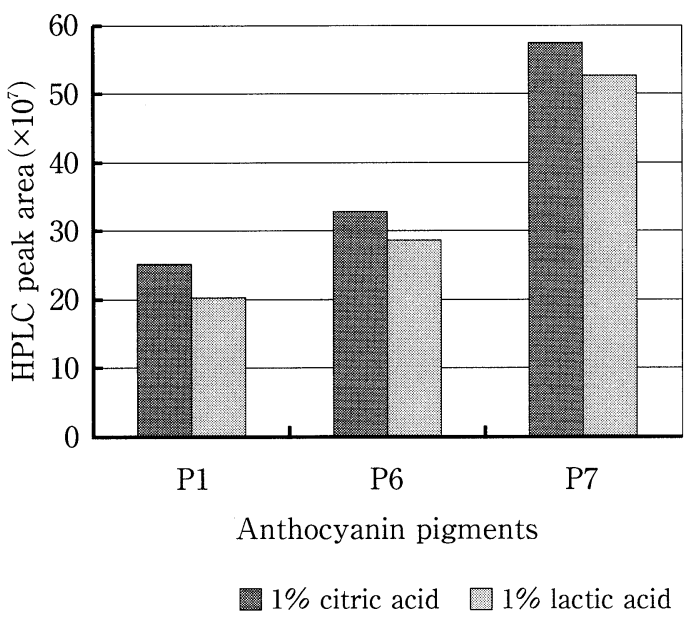

Fig. 7 Effect of solvents on extraction yield of principal AN pigments

P 1 : Cyanidin (Cy) 3-O- $(\beta$-D-glucopyranosyl (Glc) $)-\beta$-D-Glc) $-5-O$ $(\beta$-D-Glc)

P 6 : Cy 3-O-(6-p-coumaryl- $\beta$-D-Glc) $-\beta$-Glc) $-5-O$ - $(\beta$-D-Glc $)$

P 7 : Cy $3-O-(2-O$-sinapyl $(\mathrm{Si})-\beta$-D-Glc $)-\beta$-Glc $)-5-O-(\beta$-D-Glc $)$

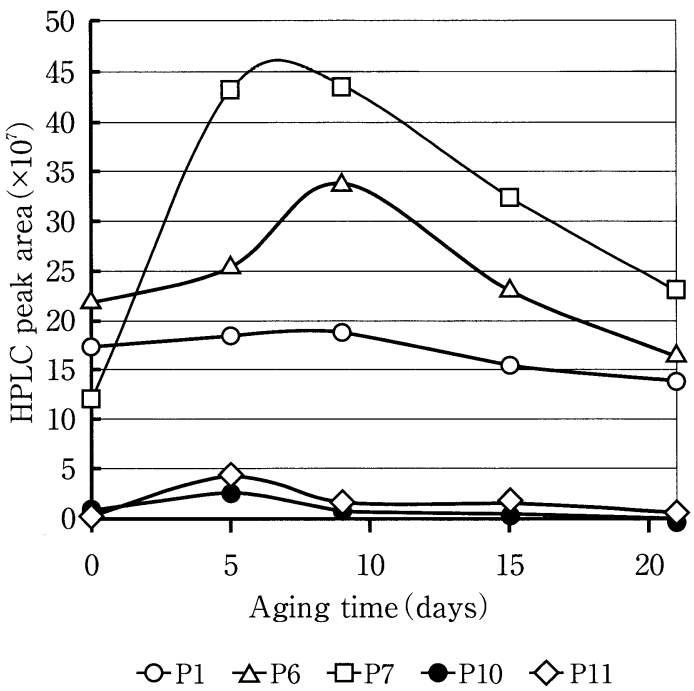

Fig. 8 Changes in principal AN pigments during maturation of pickled red cabbage

P 1 : Cyanidin (Cy) 3-O- ( $\beta$-D-glucopyranosyl (Glc) ) $-\beta$-D-Glc) -5- $O$ $(\beta$-D-Glc)

P 6 : Cy 3- $O$ - (6-p-coumaryl- $\beta$-D-Glc) $-\beta$-Glc) $-5-O-(\beta$-D-Glc $)$

P 7 : Cy $3-O-(2-O-\sin a p y l(\mathrm{Si})-\beta$-D-Glc $)-\beta-\mathrm{Glc})-5-O-(\beta-\mathrm{D}-\mathrm{GlC})$

P10 : Cy 3-O - (6-O -ferulyl-2-O- ( 2-O-Si- $\beta$-D-Glc $)-\beta$-D-Glc $)-5$ - ( $\beta$-D$\mathrm{Glc}$ )

P11 : Cy 3- $O$ - $(6-O$-Si-2- $O$ - $(2-O-\mathrm{Si}-\beta$-D-GlC $)-\beta$-D-GlC $)-5-O$ - $(\beta$-D-Glc $)$

HPLC conditions: same as those in Fig. 5.

maturation method may be used in preparing $\mathrm{AN}$ pigments.

\section{References}

1) Food Chemical NEWS: The demand item of the coloring fee: The Food chemical News, January 15 day (2004)

2 ) Tsukui, A.: Stability of Anthocyanin Pigments of Philippine Powdered Purple Yam-Effect of $\mathrm{pH}$, Heat, Light and Oxygen-, Nippon Kasei Gakkaishi, 39, 209 215 (1988)

3 ) Tsukui, A.: Stability of Anthocyanin Pigments of Philippine Powdered Purple Yam-Effect of Inorganic Salts, Organic Acid, Sugars, Phenols, LAscorbic Acid and Hydrogen Peroxide-, Nippon Kasei Gakkaishi, 40, 15 22 (1989)

4) Hayashi, K., Ohara, N. and Tsukui, A.: Stability of Anthocyanins in Various Vegetables and Fruits, Food Sci Technol., Int., 2, 30 33 (1996)

5 ) Ooba, R., Igarashi, K. and Tsukui, A. : Anthocyanins-Food Color with Health Benefits (Kenpakusha Co., Ltd., Tokyo). pp. 103 186 (2000) 


\section{赤キャベツ漬物 “Sauerkraut”製造法による アントシアニン色素製剤の検討}

村上智子 ${ }^{* 1} \cdot$ 林 $一 也^{* 2} \cdot$ 津久井亜紀夫 ${ }^{* 1}$

* 1 東京家政学院短期大学

（甬102-8341＼cjkstart東京都千代田区三番町22）

* 2 和田製糖(㭌)開発部研究室

（テ132-0021 東京都江戸川区中央 3-15-28）

赤キャベツ漬物熟成中のアントシアニン（AN）色素 抽出量について, $\mathrm{pH}$, 酸量, 食塩量, 吸光度, 褐変度, 色調，LC/MS分析およびHPLCを行い，以下の結果か ら赤キャベッ漬物熟成法がAN色素製郕として利用でき ることが認められた。(1) 赤キャベッ漬物熟成中で, 熟 成 $5 \sim 9$ 日目が $\mathrm{pH}$ の低下, 酸量の増加に伴い, 吸光度 は若干増加傾向を示した。褐変度は大きな変化はなく, 色調は赤色を濃くするが，熟成期間が長くなるとくすん
だ赤色に変化した。(2) 赤キャベツANの構造は, P 1 ： cyanidin $\lceil\mathrm{Cy}\rceil 3-O$ - (2- $O$ - $\beta$-D-glucopyranosyl $\lceil\mathrm{Glc}])-\beta$ -D-Glc $]-5-O-(\beta$-D-Glc $)], \mathrm{P} 6$ : [Cy-3-O- $(2-O-(6$ $O$-p-coumaryl $[p \mathrm{C} 〕-\beta$-D-Glc $))-5-O-(\beta$-D-Glc $)], P$ $7:[\mathrm{Cy}-3-O-(2-O-(2-O$-sinapyl〔Si $]-\beta-\mathrm{D}-\mathrm{Glc}))-5$ $O-(\beta$-D-Glc) $]$, P 9 : $[\mathrm{Cy}-3-O-(6-O-p \mathrm{C}-2-O-(2-O-\mathrm{Si}-$ $\beta$-D-Glc $))-(5-O-(\beta$-D-Glc $)), \mathrm{P} 10:(\mathrm{Cy}-3-O-(6-O$ ferulyl〔Fr $-2-O-(2-O-\mathrm{Si}-\beta-\mathrm{D}-\mathrm{Glc}))-5-O-(\beta-\mathrm{D}-$ $\mathrm{Glc})]$ and $\mathrm{P} 11:[\mathrm{Cy}-3-O-(6-O-\mathrm{Si}-2-O-(2-O-\mathrm{Si}-\beta-\mathrm{D}-$ $\mathrm{Glc}))-5-O$ - ( $\beta$-D-Glc)] と推定した。(3) 全AN色素の抽 出量は赤キャベッ熟成日数 $5 \sim 9$ 日目において最もよか った。赤キャベッANの中でアシル化していないP 1 の 抽出量は 0 ～21日目までほぼ同じであったが，アシル化 ANであるP 6 およびP 7 は赤キャベツ漬物熟成の 9 日目 まで抽出量が増加した。そしてこれら 3 つの色素が発酵 赤キャベツの主要なANであった。

(平成17年 2 月 4 日受付，平成17年 6 月 23 日受理) 